\title{
Letter to the Editors: Comparing surgical interventions for intertrochanteric hip fracture by blood loss and operation time: a network meta-analysis
}

\author{
Peng Luo ${ }^{1 *}$, Ding $X u^{2}$ and Wei Jun Guo ${ }^{1}$
}

Recently, we read the publication written by Zhengan Hao and his colleagues with great interest (Hao Z, Wang $\mathrm{X}$ and Zhang $\mathrm{X}$. Comparing surgical interventions for intertrochanteric hip fracture by blood loss and operation time: a network meta-analysis. J Orthop Surg Res. 2018 Jun 22;13(1):157). The authors carried out a meta-analysis to help surgeons choose the appropriate treatments for patients with intertrochanteric hip fractures through the perspectives of blood loss and operation times. However, we have to point out several deficiencies of this study, as some of them might lead to the bias of conclusions. Firstly, we noted that the numerical sequences of included studies in the text were inconsistent with that in the reference list. It would make readers hard to find the reference they are interested in. Secondly, in our opinion, it might be better to exclude the publication written by Garg et al. (2011) [1] in this meta-analysis, as it was retracted in 2012 due to infringements of professional ethical codes [2]. Thirdly, it is worth to note that there might be an overlapping part of patients in this meta-analysis, because three articles involved in this study actually come from the same department during an overlapping period [3-5]. Finally, the authors stated that they extracted the blood loss from each study by measuring the change from baseline. In our view, the authors should describe more details on this issue, because the measurement methods of blood loss among the studies were inconsistent. For example, Kosygan et al. used the postoperative fall of $\mathrm{Hb}(\mathrm{g} \%)$ to present the blood loss [6]. In Ahrengart et al.'s study, the blood loss was composed by different parts, including hemoglobin at

\footnotetext{
* Correspondence: luopeng19850019@163.com

${ }^{1}$ Department of Orthopedics, The Second Affiliated Hospital and Yuying

Children's Hospital of Wenzhou Medical University, Wenzhou, China
}

Full list of author information is available at the end of the article admission, perioperative blood loss, blood loss to drainage, number of blood transfusions, and hemoglobin 1 week postoperatively [7]. However, Changyou et al. only reported the intraoperative bleeding in their study [8]. As the deficiencies we mentioned above, the conclusions of this review might be limited.

\author{
Acknowledgements \\ None. \\ Funding \\ None. \\ Availability of data and materials \\ Not applicable.

\section{Authors' contributions} \\ PL wrote this manuscript, DX and WG reviewed the selected studies in Hao \\ et al.'s review. All authors read and approved the final manuscript.
}

Ethics approval and consent to participate Not applicable.

\section{Consent for publication \\ Not applicable.}

Competing interests

The authors declare that they have no competing interests.

\section{Publisher's Note}

Springer Nature remains neutral with regard to jurisdictional claims in published maps and institutional affiliations.

\section{Author details \\ 'Department of Orthopedics, The Second Affiliated Hospital and Yuying Children's Hospital of Wenzhou Medical University, Wenzhou, China. ${ }^{2}$ Department of Orthopedics, Shangyu People's Hospital of Shaoxing City, Shaoxing, China.}

Received: 15 March 2019 Accepted: 14 May 2019

Published online: 22 May 2019

\section{References \\ 1. Garg B, Marimuthu K, Kumar V, Malhotra R, Kotwal PP. Outcome of short proximal femoral nail antirotation and dynamic hip screw for fixation of}


unstable trochanteric fractures. A randomised prospective comparative trial. Hip Int. 2011;21:531-6.

2. Spencer RF. Retraction: "Outcome of short proximal femoral nail antirotation and dynamic hip screw for fixation of unstable trochanteric fractures. A randomised prospective comparative trial" [Hip Int 2011; 21(05): 531-6]. Hip Int. 2012;22:487.

3. Yaozeng X, Dechun G, Huilin Y, Guangming Z, Xianbin W. Comparative study of trochanteric fracture treated with the proximal femoral nail antirotation and the third generation of gamma nail. Injury. 2010;41:1234-8.

4. Xu YZ, Geng DC, Mao HQ, Zhu XS, Yang HL. A comparison of the proximal femoral nail antirotation device and dynamic hip screw in the treatment of unstable pertrochanteric fracture. J Int Med Res. 2010;38:1266-75.

5. Zou J, Xu Y, Yang H. A comparison of proximal femoral nail antirotation and dynamic hip screw devices in trochanteric fractures. J Int Med Res. 2009:37:1057-64.

6. Kosygan KP, Mohan R, Newman RJ. The Gotfried percutaneous compression plate compared with the conventional classic hip screw for the fixation of intertrochanteric fractures of the hip. J Bone Joint Surg Br. 2002;84:19-22.

7. Ahrengart L, Tornkvist $H$, Fornander P, Thorngren KG, Pasanen L, Wahlstrom $P$, et al. A randomized study of the compression hip screw and Gamma nail in 426 fractures. Clin Orthop Relat Res. 2002:209-22.

8. Changyou T, Zhong X, Xiang S. Prospective study of artificial femoral head replacement and DHS internal fixation for comminuted femoral intertrochanteric fractures in elderly patients. Chin J Bone Joint Injury. 2009:6.

Ready to submit your research? Choose BMC and benefit from:

- fast, convenient online submission

- thorough peer review by experienced researchers in your field

- rapid publication on acceptance

- support for research data, including large and complex data types

- gold Open Access which fosters wider collaboration and increased citations

- maximum visibility for your research: over $100 \mathrm{M}$ website views per year

At $\mathrm{BMC}$, research is always in progress.

Learn more biomedcentral.com/submissions 